\title{
PENGARUH PELATIHAN DAN PROMOSI PEGAWAI TERHADAP PRESTASI KERJA PEGAWAI
}

\author{
${ }^{1}$ Sihabudin \\ Universitas Buana Perjuangan Karawang \\ Program Studi Manajemen, Fakultas Ekonomi dan Bisnis, Universitas Buana Perjuangan \\ Karawang \\ sihabudin@ubpkarawang.ac.id ${ }^{1}$
}

Penelitian ini memiliki tujuan untuk mengetahui, menjelaskan dan menganlisis pelatihan, promosi pegawai, dan prestasi kerja pegawai Balai Besar Penelitian Tanaman Padi (BBPADI) Subang. Selanjutnya menjelaskan besaran hubungan pelatihan dan promosi pegawai, menjelaskan besaran pengaruh pelatihan terhadap Prestasi Kerja pegawai, menjelaskan besaran pengaruh promosi pegawai terhadap kinerja pegawai baik parsial maupun simultan. Dengan menggunakan pendekatan path analysis dalam menganalisis mengenai hubungan kausal dengan tujuan memisahkan pengaruh langsung dan pengaruh tidak langsung suatu variabel penyebab terhadap variabel akibat. Jumlah sampel yang diambil 150 responden dengan teknik Disproportionate Stradtified Random Sampling. Artikel ini diharapkan dapat memberikan sumbangan bagi pengembangan bidang manajemen khususnya manajemen sumber daya manusia.

Kata kunci: Sumber Daya Manusia, Analisis Kinerja Pegawai, Promosi Pegawai

\section{PENDAHULUAN}

Sumber daya manusia saat ini telah menjadi bagian terpenting yang harus dimiliki oleh suatu perusahaan. Salah satu implikasinya adalah bahwa investasi terpenting yang mungkin dilakukan oleh suatu organisasi adalah di bidang sumber daya manusia. Sumber daya manusia mempunyai peran utama dalam setiap kegiatan perusahaan. Walaupun di dukung dengan sarana dan prasarana serta sumber dana yang berlebihan, tetapi tanpa dukungan sumber daya manusia yang handal kegiatan perusahaan tidak akan terselesaikan dengan baik. Hal ini menunjukkan bahwa sumber daya manusia merupakan kunci pokok yang harus diperhatian.

Pada dasarnya setiap perusahaan memiliki satu tujuan. Untuk dapat mewujudkan tujuan tersebut perusahaan memerlukan sumber daya manusia yang baik dan selalu berperan aktif dalam setiap kegiatan nya. Bahkan perusahaan yang sudah berskala menengah dan besar juga harus mampu melakukan rekrutmen dan seleksi secara akurat setiap membutuhkan tenaga kerja 
baru, dengan didasari perencanaan sumber daya manusia yang akurat diharapkan perusahaan dapat memiliki tenaga kerja yang berkualitas dan kompetitif, tenaga kerja tersebut agar dapat dipertahankan dan dikembangkan guna mengantisipasi perubahan lingkungan bisnis yang berlangsung sangat cepat di masa-masa mendatang.

Bertahan dan meningkat nya kinerja perusahaan tergantung dari sumber daya manusia yang bekerja di dalamnya. Hal ini tentu saja tidak hanya berpengaruh di perusahaan besar saja tetapi untuk perusahaan kecil mengengah pun berlaku hal yang sama. Termasuk organisasi BUMN yang dapat memberikan kontribusi pada pemerintah daerah maupun pusat, artinya secara nasional maupun regional dapat menunjang perekonomian secara makro maupun mikro. Tentu banyak faktor-faktor yang dapat mempengaruhi, maka dengan demikian perusahaan harus berusaha menjamin agar faktor yang berkaitan dengan sumber daya manusia dapat dipenuhi secara maksimal, salah satu faktor yang mempengaruhi dalah pelatihan kerja pada karyawan.

Kinerja perusahaan secara umum dapat dilihat dari prestasi kerja karyawannya agar terwujudnya hal tersebut maka karyawan sudah seharusnya diberikan pelatihan yang sesuai dengan tugasnya masing-masing sehingga karyawan dapat mengembangkan kinerja perusahaan, namun perusahaan belum menyadari pentingnya pelatihan sehingga karyawan sulit untuk meningkatkan prestasinya, faktor lain yang yang dapat meningkatkan prestasi kerja karyawan yaitu dengan memberikan promosi kepada pegawai yang berkompeten, tetapi yang banyak terjadi di perusahaan saat ini promosi yang diberikan tidak berdasarkan asas keadilan sehingga menyebabkan perusahaan BUMN yang di privasi oleh pemerintah.

Pelatihan merupakan salah satu alat untuk menyesuaikan antara tugas dan pekerjaan dengan kemampuan, keterampilan atau kecakapan dan keahlian dari setiap karyawan serta merupakan usaha untuk meningkatkan kinerja karyawan sebagai kegiatan pengenalan terhadap pekerjaan tertentu bagi yang bersangkutan. Baik tidaknya kinerja karyawan jelas akan mempengaruhi kestabilan sebuah organisasi dalam mencapai tujuan yang ditetapkan.

Latihan-latihan yang diberikan pada karyawan akan mendorong karyawan bekerja lebih keras. Hal ini disebabkan karyawan yang telah mengetahui dengan baik tugas-tugas dan tanggung jawab akan berusaha mencapai tingkat moral kerja yang lebih tinggi. Pengetahuan karyawan maupun pengetahuan umum yang mempengaruhi pelaksanaan tugas sangat menentukan berhasil tidaknya pelaksanaan tugas tersebut. Karyawan yang kurang memiliki pengetahuan cukup tentang bidang kerjanya akan tersendat-sendat. Oleh karena itu bagi karyawan baru atau karyawan lama yang dihadapkan pada pekerjaan baru memerlukan tambahan pengetahuan dan 
keterampilan guna melaksanakan tugasnya dengan baik. Pendidikan dan pelatihan sangat penting untuk dilakukan, karena itu merupakan cara yang tepat untuk digunakan oleh organisasi/perusahaan untuk mempertahankan, menjaga, dan memelihara karyawan sekaligus meningkatkan keahlian karyawan sehingga prestasi kerja yang optimal dapat dicapai.

Pengaruh pelatihan terhadap prestasi kerja dalam setiap perusahaan tentu akan berbeda-beda , tetapi perusahaan yang dapatberkembang dengan baik, pada umumnya adalah perusahaan yang selalu melakukan inovasi secara terus-menerus yang tentu dibarengi dengan program pelatihan yang baik. Dengan demikian, perusahaan yang inovatif adalah mereka yang selalu memberikan pendidikan dan pelatihan pada karyawannya. Penghargaan atas prestasi kerja biasanya dinyatakan dalam bentuk promosi jabatan. Seorang pegawai memandang promosi sebagai sesuatu yang paling menarik dibandingkan dengan kompensasi lain, hal ini disebabkan karena promosi bersifat permanen dan berlaku untuk jangka waktu yang lama.

Balai Besar Penelitian Tanaman Padi (BB Padi) cabang Sukamandi Subang merupakan BUMN yang bergerak di bidang pertanian, tidak dapat menghindar lagi dari persaingan bisnis yang semakin terbuka di dalam berbagai sektor ekonomi. Balai Besar Penelitian Tanaman Padi (BB Padi) cabang Sukamandi Subang membutuhkan sumber daya manusia yang berkualitas tinggi, karena selain mesin-mesin yang terlibat dalam kegiatan operasional perusahaan, manusia juga merupakan "intangible asset" yang memiliki peran penting dalam operasi perusahaan. BBPadi dituntut untuk lebih memperhatikan aspek sumber daya manusia yang dimilikinya agar dapat tercipta karyawan yang profesional, tangguh, cekatan, cerdas, dan berpandangan ke depan.

\section{METODE PENELITIAN}

Metode penelitian pada dasarnnya merupakan cara ilmiah untuk mendapatkan data dengan tujuan dan kegunaan tertentu. Cara ilmiah kegiatan penelitian itu didasarkan pada ciri-ciri keilmuan, yaitu rasional, empiris, dan sistematis (Sugiyono, 2013:2). Pada Penelitian ini menggunakan metode penelitian deskriptif dan verifikatif.

Menurut Sugiyono (2013:5), penelitian deskriptif adalah penelitian yang dilakukan untuk mengetahui nilai variabel mandiri, baik satu variabel atau lebih (independen) tanpa membuat perbandingan, atau menghubungkan dengan variabel yang lain. Penelitian verifikatif menurut Sugiyono (2013:13), adalah metode penelitian kuantitatif dapat diartikan sebagai metode penelitian yang digunakan untuk meneliti populasi atau sampel tertentu, dan analisis data bersifat statistik dengan tujuan untuk menguji hipotesis yang telah ditetapkan. 
Vol. 1, No. 1, November 2016

Secara deskriptif penelitian ini bertujuan untuk memperoleh gambaran mengenai variabel kualitas pelayanan dan diversifikasi produk sebagai variabel bebasnya dan variabel Keputusan Pembelian sebagai variable terikat. Sedangkan secara verfikatif bertujuan untuk menguji hipotesis dengan perhitungan statistik.

\section{Instrumen Penelitian}

Pada prinsipnya meneliti adalah melakukan pengukuran, maka harus ada alat ukur yang baik. Alat ukur dalam penelitian biasanya dinamakan instrumen penelitian. Jadi instrumen penelitian adalah suatu alat yang digunakan mengukur fenomena alam maupun sosial yang diamati. Secara spesifik semua fenomena ini disebut variabel.

Variabel penelitian merupakan konsep utama dari kajian yang akan diteliti. Untuk lebih jelasnya maka variabel harus disederhanakan dalam sub variabel atau dimensi kajian sesuai teori yang digunakan dalam penelitian. Selanjutnya variabel harus dapat diukur dengan indikator-indikator agar dapat teridentifikasi lebih detail sesuai teori dan kajian lapangan. Untuk lebih jelasnya dapat dilihat dalam tabel sebagai berikut:

Tabel 1 Instrumen penelitian

\begin{tabular}{|c|c|c|c|}
\hline Variabel & Subvariabel & Indikator & $\begin{array}{c}\text { Nomor } \\
\text { Pertanyaan }\end{array}$ \\
\hline \multirow[t]{2}{*}{$\begin{array}{l}\text { Pelatihan } \\
\qquad\left(\mathrm{X}_{1}\right)^{*}\end{array}$} & $\begin{array}{l}\text { 1. Prinsip-Prinsip } \\
\text { Pelatihan }\end{array}$ & $\begin{array}{l}\text { 1.Partisipasi } \\
\text { 2. Repetisi (Pengulangan) } \\
\text { 3. Relevansi } \\
\text { 4. Pengalihan } \\
\text { 5. Umpan Balik }\end{array}$ & $\begin{array}{l}1 \\
2 \\
3 \\
4 \\
5\end{array}$ \\
\hline & $\begin{array}{l}\text { 2. Metode/Teknik } \\
\text { Pelatihan }\end{array}$ & $\begin{array}{l}\text { 6. Pelatihan Dalam Jabatan } \\
\text { 7. Rotasi pekerjaan } \\
\text { 8. Sistem Magang } \\
\text { 9. Sistem Ceramah } \\
\text { 10. Pelatihan Vestibule (keterampilan) } \\
\text { 11. Role-Playing Methode/Bermain Peran } \\
\text { 12. Studi Kasus } \\
\text { 13. Simulasi } \\
\text { 14. Sensitivity Training/Pelatihan Kepekaan } \\
\text { 15. Studi Sendiri }\end{array}$ & $\begin{array}{l}6 \\
7 \\
8 \\
9 \\
10 \\
11 \\
12 \\
13 \\
14 \\
15\end{array}$ \\
\hline \multirow[t]{2}{*}{$\begin{array}{c}\text { Promosi } \\
\text { Pegawai } \\
\left(\mathrm{X}_{2}\right)^{* *}\end{array}$} & $\begin{array}{l}\text { 1. Asas-Asas } \\
\text { Promosi }\end{array}$ & $\begin{array}{l}\text { 1. Kepercayaan } \\
\text { 2. Keadilan } \\
\text { 3. Formasi }\end{array}$ & $\begin{array}{l}1 \\
2 \\
3\end{array}$ \\
\hline & $\begin{array}{l}\text { 2. Dasar-Dasar } \\
\text { Promosi }\end{array}$ & $\begin{array}{l}\text { 4. Pengalaman } \\
\text { 5. Kecakapan } \\
\text { 6. Kombinasi Pengalaman Dan Kecakapan }\end{array}$ & $\begin{array}{l}4 \\
5 \\
6\end{array}$ \\
\hline
\end{tabular}




\begin{tabular}{|l|l|l|l|}
\hline \multirow{2}{*}{$\begin{array}{l}\text { 3. Syarat-Syarat } \\
\text { Promosi }\end{array}$} & 7. Kejujuran & 7 \\
& 8. Disiplin & 8 \\
& 9. Prestasi Kerja & 9 \\
& 10. Kerjasama & 10 \\
& 11. Loyalitas & 11 \\
& 12. Kepemimpinan & 12 \\
& 13. Komunikatif & 13 \\
& 14. Pendidikan & 14,15 \\
\hline
\end{tabular}

\section{Waktu dan Tempat Penelitian}

Khususnya untuk penelitian kualitatif dan kuantitatif, waktu dan tempat penelitian perlu dituliskan secara jelas.

\section{Target/Subjek Penelitian}

Target/subjek penelitian (untuk penelitian kualitatif) atau populasi-sampel (untuk penelitian kuantitatif) perlu diuraikan dengan jelas dalam bagian ini. Perlu juga dituliskan teknik memperoleh subjek (penelitian kualitatif) dan atau teknik samplingnya (penelitian kuantitatif).

\section{Prosedur Penelitian}

Prosedur perlu dijabarkan menurut tipe penelitiannya. Bagaimana penelitian dilakukan dan data akan diperoleh, perlu diuraikan dalam bagian ini. Untuk penelitian eksperimental, jenis rancangan (experimental design) yang digunakan sebaiknya dituliskan di bagian ini.

\section{Data, Instrumen, dan Teknik Pengumpulan Data}

Macam data, bagaimana data dikumpulkan, dengan instrumen yang mana data dikumpulkan, dan bagaimana teknis pengumpulannya, perlu diuraikan secara jelas dalam bagian ini

\section{Teknik Analisis Data}

Bagaimana memaknakan data yang diperoleh, kaitannya dengan permasalahan dan tujuan penelitian, perlu dijabarkan dangan jelas.

(Catatan: Sub-subbab bisa berbeda, menurut jenis atau pendekatan penelitian yang digunakan. Jika ada prosedur atau langkah yang sifatnya sekuensial, dapat diberi notasi (angka atau huruf) sesuai posisinya).

\section{HASIL DAN PEMBAHASAN}

\section{Karakteristik Responden}

Tabel 2 menyajikan data mengenai jenis kelamin responden, pada tabel tersebut terlihat bahwa responden laki-laki sebanyak 115 (77\%), lebih banyak dibandingkan responden perempuan dengan jumlah 35 orang (23\%). 
Tabel 2. Responden

\begin{tabular}{|c|c|c|c|}
\hline No & Jenis Kelamin & Jumlah & Presentase \\
\hline 1 & Laki-Laki & 115 & $77 \%$ \\
\hline 2 & Perempuan & 35 & $23 \%$ \\
\hline & Jumlah & $\mathbf{1 5 0}$ & $\mathbf{1 0 0 \%}$ \\
\hline
\end{tabular}

Tabel 3. Karakteristik responden

\begin{tabular}{|c|l|c|c|}
\hline No & \multicolumn{1}{|c|}{ Jabatan } & Jumlah Pegawai & Presentase \\
\hline 1 & Profesor Riset & 1 & $1 \%$ \\
\hline 2 & Peneliti Utama & 5 & $3 \%$ \\
\hline 3 & Peneliti Madya & 12 & $8 \%$ \\
\hline 4 & Peneiti muda & 14 & $9 \%$ \\
\hline 5 & Peneliti Pertama & 21 & $14 \%$ \\
\hline 6 & Penyelia & 9 & $6 \%$ \\
\hline 7 & Pelaksana Lanjutan & 1 & $1 \%$ \\
\hline 8 & Pelaksana & 3 & $2 \%$ \\
\hline 9 & Pemula & 14 & $9 \%$ \\
\hline 10 & Pustakawan & 1 & $1 \%$ \\
\hline 11 & Arsiparis & 67 & $1 \%$ \\
\hline 12 & Staf Pendukung & 150 & $45 \%$ \\
\hline & \multicolumn{2}{|c|}{ Jumlah } & $100 \%$ \\
\hline
\end{tabular}

Table 4 Karakteristik responden berdasar masa kerja

\begin{tabular}{|c|c|c|c|}
\hline No & Masa Kerja & Jumlah & Presentase \\
\hline 1 & $\leq 1$ tahun & 15 & $10 \%$ \\
\hline 2 & $1-10$ tahun & 94 & $63 \%$ \\
\hline 3 & $11-20$ tahun & 29 & $19 \%$ \\
\hline 4 & $\geq 20$ tahun & 12 & $8 \%$ \\
\hline & Jumlah & $\mathbf{1 5 0}$ & $\mathbf{1 0 0 \%}$ \\
\hline
\end{tabular}

Tabel 3 menyajikan data mengenai jabatan responden, pada tabel tersebut terlihat bahwa jabatan Profesor Riset sebanyak 1 orang (1\%), peneliti utama sebanyak 5(3\%),peneliti madya sebanyak 12 orang (8\%),peneliti muda sebanyak 14 orang (9\%),peneliti pertama sebanyak 21 orang (14\%), penyelia sebanyak 9 orang (6\%), pelaksana lanjutan sebanyak 1 orang (1\%), pelaksana sebanyak 3 orang (2\%), pemula sebanyak 14 orang (9\%), pustakawan sebanyak 2 orang (1\%), arsiparis sebanyak 1 orang (1\%), staf pendukung sebanyak 67 orang(45\%). Tabel 4 menyajikan data mengenai masa kerja responden, pada tabel tersebut terlihat bahwa masa 
kerja responden $\leq 1$ tahun sebanyak 15 orang (10\%), 1-10 tahun sebanyak 94 orang (63\%), 1120 tahun sebanyak 29 orang $(19 \%), \geq 20$ tahun sebanyak 12 orang (8\%).

Tabel 5 Rekapitulasi Analisis Variabel Pelatihan

\begin{tabular}{|c|c|c|c|}
\hline No & Indikator & Skor & Keterangan \\
\hline 1 & Partisipasi & 571 & $\mathrm{~B} / \mathrm{S}$ \\
\hline 2 & Pengulangan & 489 & $\mathrm{CB} / \mathrm{CS}$ \\
\hline 3 & Relevansi & 523 & $\mathrm{~B} / \mathrm{S}$ \\
\hline 4 & Pengalihan & 558 & $\mathrm{~B} / \mathrm{S}$ \\
\hline 5 & UmpanBalik & 583 & $\mathrm{~B} / \mathrm{S}$ \\
\hline 6 & Pelatihan Dalam Jabatan & 495 & $\mathrm{CB} / \mathrm{CS}$ \\
\hline 7 & Rotasi Pekerjaan & 582 & $\mathrm{~B} / \mathrm{S}$ \\
\hline 8 & Sistem Magang & 503 & $\mathrm{CB} / \mathrm{CS}$ \\
\hline 9 & Sistem Ceramah & 502 & $\mathrm{CB} / \mathrm{CS}$ \\
\hline 10 & Pelatihan Keterampilan & 585 & $\mathrm{~B} / \mathrm{S}$ \\
\hline 11 & Bermain Peran & 588 & $\mathrm{~B} / \mathrm{S}$ \\
\hline 12 & Studi Kasus & 551 & $\mathrm{~B} / \mathrm{S}$ \\
\hline 13 & Simulasi & 527 & $\mathrm{~B} / \mathrm{S}$ \\
\hline 14 & Pelatihan Kepekaan & 565 & $\mathrm{~B} / \mathrm{S}$ \\
\hline \multirow[t]{3}{*}{15} & Studi Sendiri & 537 & $\mathrm{~B} / \mathrm{S}$ \\
\hline & Jumlah : & 8159 & \\
\hline & Rata-rata : & 544 & $B / S$ \\
\hline
\end{tabular}

Hasil rekapitulasi analisis rentang skala sebagaimana tersebut diatas, diperoleh total skor 8159 dan rata-rata skor sebesar 544. Tanggapan responden mengenai pelatihan yang selama ini diadakan di lingkungan Balai Besar Penelitian Tanaman Padi Subang berada pada kriteria Baik/Setuju. Skala Baris (Bar Scale) dapat digambarkan sebagai berikut:

STS

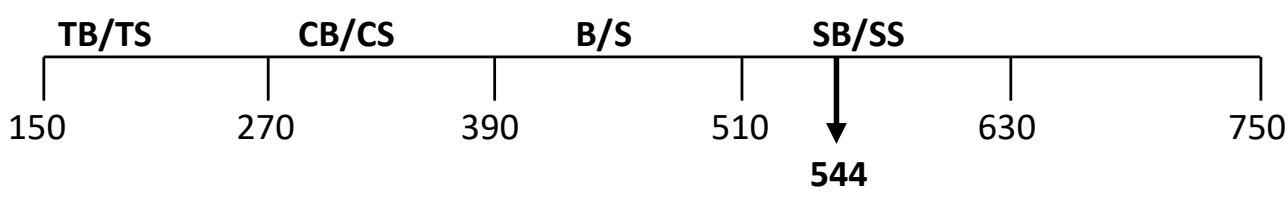

Gambar 1 Rekapitulasi analisis pelatihan

Adapun pembahasan metode verifikatif dalam penelitian ini dapat diuraikan sebagai berikut :

1. Hubungan antara pelatihan $\left(X_{1}\right)$ dengan Promosi Pegawai $\left(X_{2}\right)$ sebesar 0,934 dan mempunyai tingkat hubungan yang sangat kuat dan searah karena nilainya positif karena interval koefisiennya terdapat pada kategori sangat kuat (Sugiyono, 2012:184). Karena jika salah satu variabel menurun atau meningkat, maka variabel lainnya akan ikut berubah, ini menunjukkan suatu hubungan yang kuat dan searah.

2. Pengaruh Parsial Pelatihan $\left(\mathrm{X}_{1}\right)$ dengan Promosi Pegawai $\left(\mathrm{X}_{2}\right)$ terhadap Prestasi Kerja (Y). 
1) Pengaruh parsial Pelatihan $\left(X_{1}\right)$ terhadap Prestasi Kerja $(Y)$ adalah 0,508.

2) Pengaruh parsial Promosi Pegawai $\left(\mathrm{X}_{2}\right)$ terhadap Prestasi Kerja (Y) adalah 0,369.

Karena 0,508 lebih besar dari 0,369, maka dapat dinyatakan bahwa variabel Pelatihan lebih banyak memberikan kontribusi terhadap Prestasi Kerja dibandingkan variabel Promosi Pegawai. Hal ini disebabkan karena responden memandang pelatihan merupakan proses peningkatan pengetahuan dan keterampilan untuk menyelesaikan pekerjaan dalam jangka yang lebih pendek ,sehingga pegawai dapat berkembang dan berkompetensi dalam mencapai sasaran-sasaran kerja yang telah ditetapkan, karena pelatihan bertujuan untuk meningkatkan prestasi kerja. Selain karena pelatihan juga karena promosi pegawai. Promosi pegawai ini akan membawa pengaruh dan kemampuan yang bersangkutan untuk menduduki jabatan yang lebih tinggi, promosi juga dapat menjadi motivasi yang mendorong setiap pegawai untuk bekerja lebih baik, lebih giat, bersemangat dalam melaksanakan pekerjaan untuk meningkatkan prestasi kerja.

3. Pelatihan (X1) dan Promosi Pegawai (X2) terhadap Prestasi Kerja (Y), dengan kriteria uji sig. $(0,000)<\alpha(0,05)$ dan fhitung $(213,679)>$ ftabel $(3,06)$, artinya H0 ditolak. Total pengaruh Pelatihan (X1) dan Promosi Pegawai (X2) terhadap Prestasi Kerja (Y) sebesar 74,4\%. Hal ini menunjukkan bahwa Pelatihan (X1) dan Promosi Pegawai (X2) memiliki kontribusi terhadap Prestasi Kerja (Y) sebesar 74,4\%, sedangkan sisanya $25.6 \%$ merupakan kontribusi variabel lain $(\varepsilon)$ yang tidak diteliti.

\section{KESIMPULAN}

Berdasarkan hasil analisis dan pembahasan mengenai pengaruh pelatihan dan promosi pegawai terhadap prestasi kerja pegawai di Balai Besar Penelitian Tanaman Padi (BBPADI) Subang, maka dapat ditarik kesimpulan sebagai berikut :

1. Pelatihan yang diadakan di Balai Besar Penelitian Tanaman Padi (BBPADI) Subang secara umum pegawai mengatakan baik/setuju. Hal itu berdasarkan hasil kuesioner dengan 15 butir pernyataan diperoleh nilai total skor sebesar 8159, nilai rata-rata sebesar 544 yang berada pada rentang skala antara 510-630. Namun masih terdapat indikator dengan nilai terendah yaitu pengulangan, pelatihan dalam jabatan, sistem magang, dan sistem ceramah. 
2. Promosi Pegawai yang diadakan di Balai Besar Penelitian Tanaman Padi (BBPADI) Subang secara umum pegawai mengatakan baik/setuju. Hal itu berdasarkan hasil kuesioner dengan 15 butir pernyataan diperoleh nilai total skor sebesar 8329 nilai ratarata sebesar 556 yang berada pada rentang skala antara 510-630. Namun masih terdapat indikator dengan nilai terendah yaitu disiplin, kepemimpinan, dan pendidikan.

3. Prestasi Kerja pegawai yang ada di Balai Besar Penelitian Tanaman Padi (BBPADI) Subang secara umum pegawai mengatakan baik/setuju. Hal itu berdasarkan hasil kuesioner dengan 15 butir pernyataan diperoleh nilai total skor 8169 nilai rata-rata sebesar 545 yang berada pada rentang skala antara 510-630. Namun masih terdapat indikator dengan nilai terendah sikap, waktu, pendidikan, dan supervisi/pengawas.

4. Koefisien korelasi diantara variabel bebas yaitu hubungan antara pelatihan dengan promosi pegawai sebesar 0,934 dan mempunyai tingkat hubungan yang sangat kuat.

5. Variabel pelatihan dan promosi pegawai secara parsial mempunyai pengaruh yang positif dan signifikan terhadap prestasi kerja pegawai.

1) Koefisien jalur variabel pelatihan secara parsial terhadap prestasi kerja pegawai adalah sebesar 0,508 .

2) Koefisien jalur variabel promosi pegawai secara parsial terhadap prestasi kerja pegawai adalah sebesar 0,369 .

6. Variabel pelatihan dan promosi pegawai secara simultan mempunyai pengaruh yang positif dan signifikan terhadap prestasi kerja pegawai. Total pengaruh pelatihan dan promosi pegawai terhadap prestasi kerja pegawai sebesar 74,4\%. Hal ini menunjukkan bahwa pelatihan dan promosi pegawai memiliki kontribusi terhadap prestasi kerja pegawai sebesar $74,4 \%$, sedangkan sisanya $25,6 \%$ merupakan kontribusi variabel lain yang tidak diteliti.

\section{DAFTAR PUSTAKA}

1. Deesler, Gary, 20088, Human Resource Management, Edisi Ketujuh, Cetakan Kedua, Penerbit Prehaulindo, Jakarta, Indonesia.

2. Deesler, Gary, 2007, Manajemen Sumber Daya Manusia, Edisi Kesepuluh, Cetakan Pertama, Penerbit PT. Indeks, Jakarta, Indonesia.

3. Handoko, T. Hani.,2011, Manajemen, Edisi Kedua, Penerbit BPFE, Yogyakarta.

4. Handoko, T. Hani.,2011, Manajemen Personalia \& Sumberdaya Manusia ,Edisi Kedua, Penerbit BPFE, Yogyakarta 
5. Hasibuan, Malayu, SP. 2010, Manajemen Dasar, Pengertian dan Masalah. Penerbit : Bumi Aksara, Jakarta.

6. 2011, Perencanaan dan Pengembangan Sumber Daya Manusia. cetakan keenam, Penerbit : Bumi Aksara, Jakarta.

7. Mangkunegara, A. A. Anwar Prabu. 2013, Manajemen Sumber Daya Manusia Perusahaan, Cetakan Dua Belas. Bandung : PT Remaja Rosdakarya

8. 2011, Manajemen Sumber Daya Manusia Perusahaan, Cetakan Kelima. Bandung : PT Refika Aditama

9. Siagian, Sondang P. 2010. Manajemen Sumber Daya Manusia. Cetakan Kedua Puluh Dua. Jakarta: Bumi Aksara

10. Sugiyono. 2012. Metode Penelitian Kuantitatif Kualitatif dan R\&D. Cetakan Keenam Belas. Bandung ALfabeta

11. Sedarmayanti, 2008, Sumber Daya Manusia dan Produktivitas Kerja, Cetakan Kedua, Mandar Maju, Bandung.

12. Simamora, Henry, 2007. Manajemen Sumber Daya Manusia, Edisi Kedua, STIE YKPN, Yogyakarta.

13. Zonyfar, C., Baihaqi, K.A., Pertiwi, A.B. (2020). Pixel value differencing and modulus function method for embedded message in digital images. International Journal of Psychosocial Rehabilitation, 24(7), 3379-3385

14. Zonyfar, C., Sihabudin, S., \& Khusaeri, A. (2019). Peningkatan Kemampuan Siswa dalam Memanfaatkan Sumber Belajar di Internet Melalui Sosialisasi Edukasi Internet Cerdas, Sehat, dan Aman. Jurnal Pengabdian Tri Bhakti, 17-20.

15. Ansori, Ahmad. 2007. Pengaruh Pelatihan Terhadap Prestasi Kerja Karyawan Pada Unit Produksi (Studi Kasus di CV Kharisma Jaya, Cirebon). Skripsi Pada Fakutlas Teknologi Pertanian. Institut Pertanian Bogor http://repository.ipb.ac.id/bitstream/handle/123456789/11878/f08aan_abstract.pdf?squenc e=1 (diakses tanggal 26 Januari 2015 jam 20:00)

16. http://hukum.unsrat.ac.id/uu/uu_13_03.htm (diakses tanggal 25 Februari 2015 jam jam $17: 53)$

17. Satrio, Abi Risky. 2012. Pengaruh Pelatihan Dan Promosi Jabatan Terhadap Prestasi Kerja Karyawan (Studi Kasus di Pt. Kereta Api (Persero) Daerah Operasi 2 Bandung). Skripsi Pada Fakultas Ekonomi Universitas Pasundan Bandung 
http://digilib.unpas.ac.id/gdl.php?mod=browse\&op=read\&id=jbptunpaspp-gdl-abisatrior2365\#.VQoIctKsWj8 (diakses pada tanggal 09 Februari 2015 jam 00:31:26)

18. Tajuddin, Sukma Juwati. 2012. Pengaruh Penilaian Prestasi Kerja Terhadap Promosi Jabatan Pada PT Semen Tonasa Kabupaten Pangkep. Skripsi Pada Fakultas Ekonomi. Universitas Hasanudin Makassar http://repository.unhas.ac.id/bitstream/handle/123456789/2235/SKRIPSI\%20LENGKAP \%20FEB-MANAJEMEN-SUKMA\%20JUWATI\%20TAJUDIN.pdf (diakses tanggal 26 Januari 2015 jam 30:30) 